\title{
Masks Save Lives for COVID 19
}

\section{Soumitra Sahana ${ }^{1 *}$, Indranil Chatterjee ${ }^{2}$, Suman Kumar Nath $^{2}$ and Snehansu Biswas ${ }^{2}$}

${ }^{1}$ B. Pharm, Birbhum Pharmacy School, Birbhum, West Bengal, India

${ }^{2}$ Assistant Professor, Birbhum Pharmacy School, Birbhum, West Bengal, India

*Corresponding Author: Soumitra Sahana, B. Pharm, Birbhum Pharmacy School, Birbhum, West Bengal, India.
Received: August 27, 2020

Published: October 28, 2020

(C) All rights are reserved by Soumitra

Sahana., et al.
Prompting others that "masks save lives" is not just sound guidance. It's a scientific truth that carrying one in public can assist to gradual the unfold of SARS-CoV-2, the virus accountable for the coronavirus Disease 2019 (COVID-19) pandemic.

I'm very cautious to put on a masks backyard my domestic every time I'm out and about. I do it now not always to guard myself, however to defend others. If by using threat I've been uncovered to the virus and am presently incubating it, I wouldn't favor to unfold it to different people. And any of us ought to be an unknowing superspreader. We owe it to anybody we encounter, in particular these who are extra vulnerable, to shield them. It's feasible to put on your masks even whilst you're outdoor exercising.

But there are nevertheless skeptics around. So, straightforwardly how lots does a facial overlaying defend these round you? Quite a bit, in accordance to researchers who created a state-ofthe-art mathematical mannequin to take a extra specific seem [1]. Their mannequin suggests that even if a neighborhood universally adopted a crude material overlaying that's a long way much less than a hundred percentage shielding towards the virus, this measure on my own ought to notably assist to decrease deaths.

These findings, funded partly via NIH, had been posted these days in Nature Communications. They come from Colin Worby, Broad Institute of MIT and Harvard, Cambridge, MA and HsiaoHan Chang, National Tsing Hua University, Taiwan. The researchers referred to numerous months in the past that hints on carrying a masks diverse throughout the United States and round the world. To assist information policymakers, the researchers simulated outbreaks in a closed, randomly interacting populace in which the grant and effectiveness of crude material or disposable, medicalcategory masks varied.

Under unique outbreak situations and masks usages, the researchers calculated the complete numbers of anticipated SARSCoV-2 infections and deaths from COVID-19. Not surprisingly, they located that the complete variety of deaths and infections declined as the availability and effectiveness of face masks increased.

The researchers' mannequin notably regarded the distribution of medical-grade, surgical masks. But due to the fact such masks are presently handy in constrained supply, they should be prioritized for use via fitness care employees and others at excessive risk. The researchers go on to be aware that the World Health Organization and others now advise carrying home made face coverings in public, in particular in locations the place the virus is spreading. While it's genuine the capability of these face coverings to incorporate the virus is extra constrained than medical-grade masks, they can assist and will lead to many fewer deaths.

Another latest paper additionally suggests that whilst sporting a masks is in particular supposed to forestall the wearer from infecting others, it can also additionally assist decrease the dose, or inoculum, of SARS-CoV-2 that the wearer would possibly get hold of from others, ensuing in milder or asymptomatic infections [2]. If correct, that's every other awesome motive to put on a mask.

Before, more than 175,000 humans in the US have died from COVID-19. The cutting-edge estimates [3] from the Institute for Health Metrics and assessment at the University of Washington's School of Medicine, Seattle, predict that the Coronavirus disease 
19 (COVID-19) loss of life toll in the U.S. can also attain almost 300,000 via December 1.

But that doesn't have to happen. As this new find out about shows, face coverings-even these that are a ways from perfectreally can and do keep lives. In fact, IHME statistics moreover disclose that constant mask-wearing-starting today-could store shut to 70,000 lives in the months to come. Saving these lives is up to all of us. Don't depart domestic barring your mask.

\section{Bibliography}

1. Worby CJ and Chang HH. "Face mask use in the general population and optimal resource allocation during the COVID 19 pandemic". Nature Communications 11.1 (2020): 4049.

2. Gandhi M., et al. "Masks Do More Than Protect others During COVID-19: Reducing the Inoculum of SARS-CoV-2 to Protect the Wearer". Journal of General Internal Medicine (2020).

3. New IHEM COVID-19 forecasts see nearly 300,000 deaths by December 1 . Institute for Health Metrics and Evaluation (2020).

\section{Assets from publication with us}

- Prompt Acknowledgement after receiving the article

- Thorough Double blinded peer review

- Rapid Publication

- Issue of Publication Certificate

- High visibility of your Published work

Website: https://www.actascientific.com/

Submit Article: https://www.actascientific.com/submission.php

Email us: editor@actascientific.com

Contact us: +919182824667 